\title{
Fragmented populations of the Vulnerable eastern hoolock gibbon Hoolock leuconedys in the Lower Dibang Valley district, Arunachal Pradesh, India
}

\author{
Kuladip Sarma, Murali Krishna and Awadhesh Kumar
}

\begin{abstract}
We conducted a survey of the distribution and population status of the eastern hoolock gibbon Hoolock leuconedys in non-protected fragmented forest areas of the Lower Dibang Valley district of Arunachal Pradesh, India, during September 2010-June 2011. We estimated the minimum population density at seven study sites by direct observation and by counting the number of vocalizations heard from groups that were out of view. We used 1-ha belt transects $(500 \times 20 \mathrm{~m})$ to estimate tree diversity in the study area. For two groups of gibbons we recorded their feeding patterns in forest fragments, using focal individual sampling, during May 2011. A total of 54 groups and three solitary individuals were recorded: 39 groups and three individuals through visual encounter and 15 groups through vocalization recognition. The mean group size recorded was $2.89 \pm \mathrm{SE}$ o.11 (range 2-4). We counted a total of 289 trees, of 26 species and 17 families, in 18 belt transect surveys covering all non-protected fragments of the Lower Dibang Valley district. The gibbons' diet consisted of seasonal fruits and figs (29\%), leaves (65\%), seeds (2\%) and flowers (0.5\%). The major threats recorded at the study sites were habitat destruction and hunting. To protect the Vulnerable eastern hoolock gibbon, conservation measures will need to involve local communities.
\end{abstract}

Keywords Conservation status, distribution pattern, eastern hoolock gibbon, fragmented population, Hoolock leuconedys, India, Lower Dibang Valley

This paper contains supplementary material that can be found online at http://journals.cambridge.org

\section{Introduction}

Toolock gibbons (genus Hoolock) occur in forested 1 areas of north-east India, Bangladesh, Myanmar and southern China (Harlan, 1934; Groves, 1972). Geographically the natural range of these apes extends from the Brahmaputra River east to the Salween River

Kuladip Sarma, Murali Krishna and Awadhesh Kumar (Corresponding author) Wildlife Research and Conservation Laboratory, Department of Forestry, North Eastern Regional Institute of Science and Technology (Deemed University), Nirjuli-791109 (Itanagar), Arunachal Pradesh, India

E-mail tpileatus@gmail.com

Received 27 April 2012. Revision requested 2 July 2012.

Accepted 23 August 2012. First published online 15 September 2014.
(Lwin et al., 2011). The genus Hoolock comprises two distinct species, the eastern hoolock gibbon Hoolock leuconedys and the western hoolock gibbon Hoolock hoolock, which are separated based on differences in fur coloration (Mootnick \& Groves, 2005; Geissmann, 2007). H. leuconedys was known to be distributed east of the Chindwin River to the Salween River in Myanmar and south-west Yunnan Province in China, at 1,067-1,219 m altitude (Groves, 1971), until it was observed in Arunachal Pradesh, India, between the Lohit River in the north and the mountains of Dafa Bum in the south (Das et al., 2006). More recently the species has been found in Sadiya Division, the easternmost part of Assam, south of the Dibang-Brahmaputra River system (Chetry \& Chetry, 2010). The population, distribution, ecology and behaviour of the western hoolock gibbon have been studied in India and Bangladesh by Alfred \& Sati (1990), Das et al. (2003), Mukherjee (1986) and Islam \& Feeroz (1992). Preliminary studies have been conducted on the eastern hoolock gibbon to explore its distribution and population status in Arunachal Pradesh and Assam, India (Chetry et al., 2008, 2010; Chetry \& Chetry, 2010). Population surveys of the eastern hoolock gibbon have also been conducted in China (Fan et al., 2011) and Myanmar (Brockelman et al., 2009; Walker et al., 2009). The eastern hoolock gibbon is categorized as Vulnerable on the IUCN Red List (Brockelman \& Geissmann, 2008) and listed as a Schedule I species in the Indian Wildlife (Protection) Act, 1972. To inform future conservation and management planning we carried out a survey of the fragmented forest areas of the Lower Dibang Valley district, Arunachal Pradesh, India, to determine the current population and conservation status of $H$. leuconedys in this region.

\section{Study area}

The study was conducted at seven sites outside Mehao Wildlife Sanctuary, in Arunachal Pradesh (Fig. 1): six sites to the south-east and north-west of the Sanctuary (Injuno, Koronu, Delo, Hawaichapori, Horupahar, Iduli) and one site to the north-west (Chidu). These seven study sites lie within two administrative circles in the Lower Dibang Valley district: Koronu Circle and Roing Circle. The study sites are at $145-390 \mathrm{~m}$ altitude and are unclassified forests, not included in any management class and under the jurisdiction of the territorial forest officer. The main forest types recorded in the area are low hills and plains semi-evergreen 


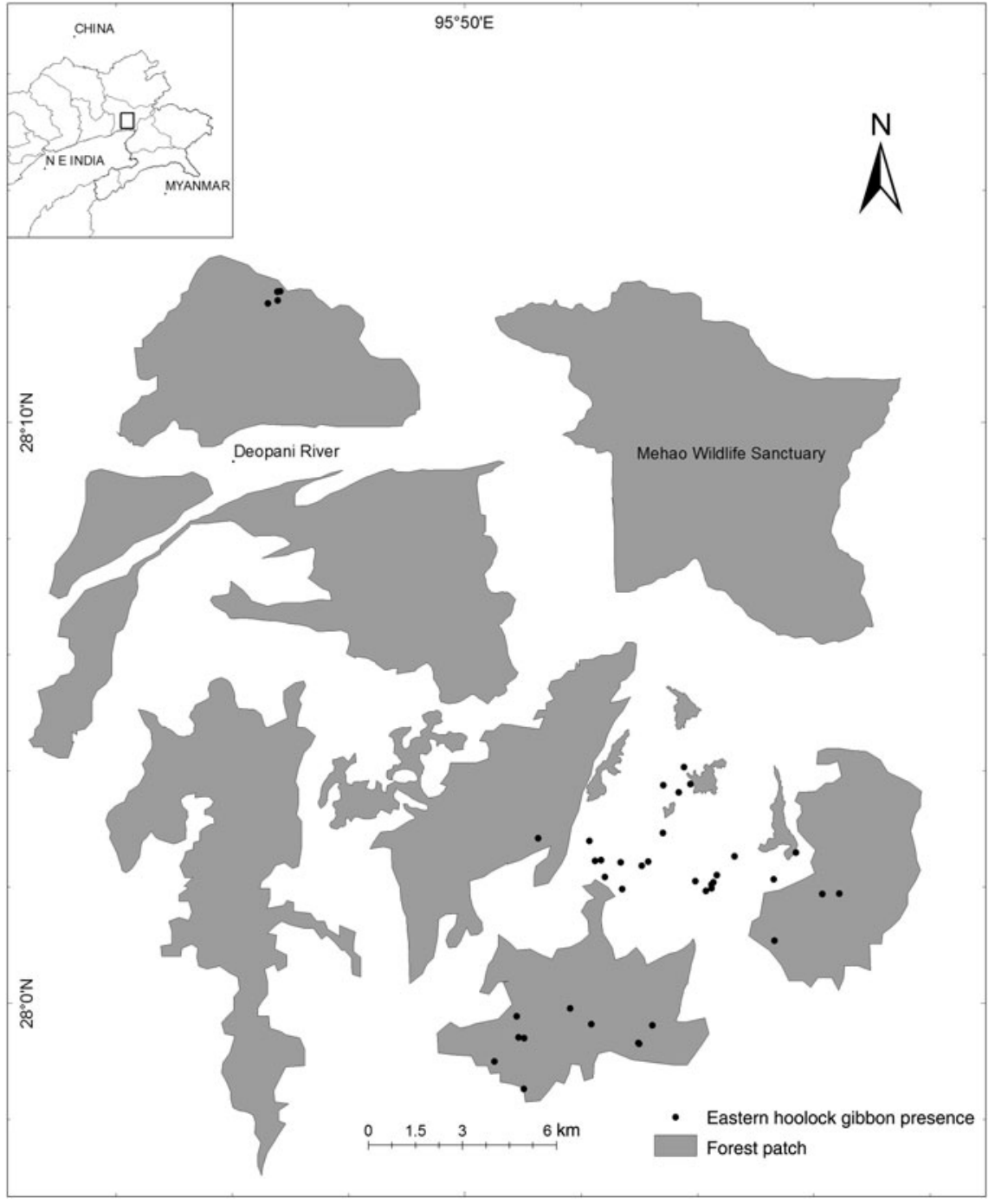

FIG. 1 The distribution of eastern hoolock gibbons Hoolock leuconedys and forest patches in the study area, in the Lower Dibang Valley district, Arunachal Pradesh, India. forest, Assam alluvial plains semi-evergreen forest $2 \mathrm{~B} / \mathrm{CIa}$ and sub Himalayan light alluvial evergreen forest $2 \mathrm{~B} / \mathrm{CI} /$ ISI (Champion \& Seth, 1968; Kaul \& Haridasan, 1987). The study area is occupied by the Idu-Mishmi and Adi peoples, who generally depend on agriculture for their livelihood. They cultivate cash crops such as ginger Zingiber officinale, maize Zea mays, mustard Brassica juncea and rice Oryza sativa.

\section{Methods}

The survey was conducted from September 2010 to June 2011. We estimated the minimum population, based on visual encounters and auditory data, and recorded group size and age-class compositions (Kakati et al., 2009). We categorized individual gibbons as adult, subadult, juvenile or infant, based on body size and coat colour (Gupta et al., 2005; Table 1).

We covered a total of $109 \mathrm{~km}$ during 33 census walks across the seven study sites (Table 2). We sighted gibbons directly from the transect and after following their calls (Kakati et al., 2009). We tried to locate all calling groups estimated to be $<500 \mathrm{~m}$ from the trail. For direct sightings we also recorded the local vegetation type and the degree of human disturbance of the habitat. We used stratified random sampling of transects to collect tree data within 18,500 $\times 20 \mathrm{~m}$ (1 ha; Sykes \& Horrill, 1977; Kumar et al., 2006). We established the transects along existing forest trails and footpaths and recorded the local names and girth of all trees $\geq$ $30 \mathrm{~cm}$ in girth at breast height.

We estimated the minimum distance between gibbon groups, using the Distance Matrix tool in QGIS (QGIS, 2012). Using the geographical information system map we calculated the distance from each group to the nearest forest patch to examine the effect of forest degradation on group size. We counted the number of trees in the patches where gibbons were located, and assigned each patch to one of the following categories: single tree, single tree in bamboo patch, 2-5 trees, 5-7 trees, and $>7$ trees. We compared the mean group size among the different categories. We analysed the 
TABLE 1 Distinguishing characteristics of male and female eastern hoolock gibbons Hoolock leuconedys in different age categories (Gupta et al., 2005).

\begin{tabular}{|c|c|c|}
\hline Age category & Sex & Distinguishing characteristics \\
\hline $\begin{array}{l}\text { Infants } 1 \text { day-2 } \\
\text { years old }\end{array}$ & $\begin{array}{l}\text { Male \& } \\
\text { female }\end{array}$ & $\begin{array}{l}20-35 \mathrm{~cm} \text { length; carried by } \\
\text { adult female; white to light grey } \\
(<1 \text { year), dark grey or black } \\
\text { ( } 1-2 \text { years old); cannot determine } \\
\text { sex in the field }\end{array}$ \\
\hline $\begin{array}{l}\text { Juveniles 2-4 } \\
\text { years old }\end{array}$ & $\begin{array}{l}\text { Male \& } \\
\text { female }\end{array}$ & $\begin{array}{l}\text { 35-44 cm length; black; distinct } \\
\text { eyebrows; never carried by mother; } \\
\text { sleep away from mother }\end{array}$ \\
\hline \multirow[t]{2}{*}{$\begin{array}{l}\text { Subadults } 4-7 \\
\text { years old }\end{array}$} & Male & $\begin{array}{l}45-52 \mathrm{~cm} \text { length; jet black; emer- } \\
\text { ging scrotum }\end{array}$ \\
\hline & Female & $\begin{array}{l}\text { Broad greyish patches on a black } \\
\text { coat }\end{array}$ \\
\hline $\begin{array}{l}\text { Adults }>7 \\
\text { years }\end{array}$ & $\begin{array}{l}\text { Male } \\
\text { Female }\end{array}$ & $\begin{array}{l}\text { Distinct scrotum and jet black coat } \\
\text { Buff-coloured coat }\end{array}$ \\
\hline
\end{tabular}

change in forest cover, using satellite images of the study area from 1985 and 2010, with ERDAS Imagine v. 9.2 (Intergraph, Madison, USA). We recorded the feeding and ranging patterns of two gibbon groups, $\mathrm{A}$ and $\mathrm{B}$, collecting data on various aspects of food and feeding for each group for 7 consecutive days in May 2011. We recorded observations every 5 minutes, with focal individual sampling (Altmann, 1974). Each group comprised one adult male and one adult female with an infant. We recorded the time spent by each individual on each food plant, and the parts eaten, along with the time spent at different feeding sites (trees, climbers and crops). Plant parts were categorized as young leaves, mature leaves, fruits/figs, flowers and seeds. The groups were habituated to the presence of humans. We followed them from dawn to dusk each day. We focused on each adult in turn, to ensure representation of all members of the group. We used SPSS v. 16.o (SPSS, Chicago, USA) for statistical analysis, using Friedman and Mann-Whitney $U$ tests to examine the differences in encounter rates and mean group sizes between the seven study sites.

\section{Results}

We estimated the total number of groups from the number of visual encounters and the vocal data. A total of 54 groups and three solitary individuals were recorded. The maximum number of groups was recorded at Iduli (17), followed by Delo (9), Horupahar (8), Koronu (7), Chidu (6), Injuno (5) and Hawaichapori (2). Of the 42 groups/individuals encountered directly, 38 groups were recorded in the Koronu Circle and four groups in the Roing Circle, at Chidu.

A total of 116 individuals in 39 groups and including 3 solitary individuals were recorded: $41(35 \%)$ adult males,
$38(33 \%)$ adult females, $16(14 \%)$ subadult males, $3(3 \%)$ subadult females and 18 (15\%) infants (Table 2 ).

The mean group size across the seven study sites was 2.89 \pm SE 0.11 (range 2-4). For individual sites the highest mean group size was 3.0 (Koronu, Injuno, Hawaichapori and Chidu) and the lowest was 2.75 (Horupahar). There was a statistically significant difference in the group size and encounter rate across the seven sites (Friedman test, $\chi^{2}=10.57, P=0.005, \mathrm{n}=7$ ). The ratio of immature (infant and subadult) to adult gibbons was the same at all sites. Group size also varied with habitat quality, specifically the number of standing trees (Fig. 2). Larger groups were found in forest patches (3.1) than in single trees (2.3). The distance of the group from the nearest forest patch also influenced the group size; smaller groups (2.5) were found at distances $>800 \mathrm{~m}$ (Fig. 3 ).

The estimated male : female ratio among adults was $1.07: 1$ across the seven study sites. The infant: female ratio was highest in the Injuno area (0.67: 1; Table 2).

The recording of gibbons in Horupahar and Hawaichapori was significant because both these fragmented forest patches are surrounded by agricultural lands and human habitation, leaving gibbons more vulnerable at these sites. There was a significant correlation between the encounter rate and the size of the study area (MannWhitney $U, Z=2.04, \mathrm{P}<0.05, \mathrm{n}=7$ ); furthermore, a higher encounter rate was observed when the mean distance between sites was lower (Fig. 4).

In the 18 transects we counted 289 trees, of 26 species (19 identified to species) and 17 families (Supplementary Table $\mathrm{S}_{1}$ ). The most common species were Ficus spp., followed by Ailanthus grandis and Bischofia javanica. The least frequently observed species was Bombax ceiba.

Satellite images of the study area for 1985-2010 show that the loss of forest cover was mainly as a result of the expansion of agricultural land, which increased by $87 \%\left(147 \mathrm{~km}^{2}\right)$. In the study area a $48 \%$ decrease in forest cover was documented during 1985-2010 (Table 3).

Based on the total feeding time during a 7-day study period, the diet of the two focal groups of gibbons consisted of fruits and figs $(29 \%)$, leaves $(65 \%)$, seeds $(2 \%)$ and flowers (0.5\%). Gibbons showed a preference for young leaves (59\%) over mature leaves $(6 \%)$.

The main threats recorded at the study sites, through general observation and interaction with local people, were habitat destruction and hunting by local people. Habitat destruction was caused mainly by expansion of permanent agricultural practices, shifting cultivation, tea plantation, and construction of a national highway and permanent settlements. The eastern hoolock gibbon is hunted mainly as an alternative source of meat, and its bones, skin and fur are used for decoration and for making bags. Domestic dogs Canis lupus familiaris kept by local people to protect their property and livestock are potential 
TABLE 2 Survey data from seven study sites in fragmented forest areas of Lower Dibang Valley district, Arunachal Pradesh, India (Fig. 1).

\begin{tabular}{|c|c|c|c|c|c|c|c|}
\hline Variables & Chidu & Injuno & Horupahar & Hawaichapori & Delo & Koronu & Iduli \\
\hline Altitude (msl) & $390-430$ & $211-283$ & $195-215$ & $198-216$ & $209-251$ & $212-259$ & $151-179$ \\
\hline Area of forest $\left(\mathrm{km}^{2}\right)$ & 0.25 & 0.91 & 2.32 & 3.50 & 4.24 & 6.97 & 15.26 \\
\hline No. of survey days & 4 & 4 & 5 & 2 & 5 & 5 & 8 \\
\hline Length of transect walked $(\mathrm{km})$ & 16.0 & 13.5 & 14.0 & 19.0 & 19.5 & 15.0 & 12.0 \\
\hline No. of groups encountered (G) & 2 & 3 & 5 & 1 & 6 & 4 & 7 \\
\hline No. of solitaries encountered (S) & 0 & 1 & 1 & 0 & 1 & 0 & 0 \\
\hline No. of groups heard/seen & 2 & 0 & 3 & 0 & 1 & 1 & 4 \\
\hline Encounter rate $(\mathrm{G}+\mathrm{S}$ per $\mathrm{km})$ & 0.13 & 0.22 & 0.35 & 0.05 & 0.30 & 0.26 & 0.58 \\
\hline Total no. of individuals & 21 & 23 & 15 & 3 & 10 & 32 & 12 \\
\hline \multicolumn{8}{|l|}{ No. of adult individuals } \\
\hline Male & 8 & 8 & 5 & 1 & 4 & 11 & 4 \\
\hline Female & 7 & 8 & 4 & 1 & 3 & 10 & 4 \\
\hline \multicolumn{8}{|l|}{ No. of subadult individuals } \\
\hline Male & 3 & 3 & 3 & 0 & 1 & 7 & 2 \\
\hline Female & 0 & 0 & 0 & 0 & 0 & 3 & 0 \\
\hline No. of infants & 3 & 4 & 2 & 1 & 2 & 4 & 2 \\
\hline Immature ${ }^{\star} /$ adult ratio & 2.0 & 2.0 & 2.2 & 2.3 & 2.5 & 2.0 & 1.9 \\
\hline Infant/female ratio & 0.50 & 0.67 & 0.50 & 1.00 & 0.43 & 0.40 & 0.40 \\
\hline Mean group size (No. of groups) & $3.00(4)$ & $3.00(3)$ & $2.75(8)$ & $3.00(1)$ & $2.86(7)$ & $3.00(5)$ & $2.91(11)$ \\
\hline No. of groups heard only & 2 & 2 & 0 & 1 & 2 & 2 & 6 \\
\hline
\end{tabular}

${ }^{\star}$ Infant + subadult

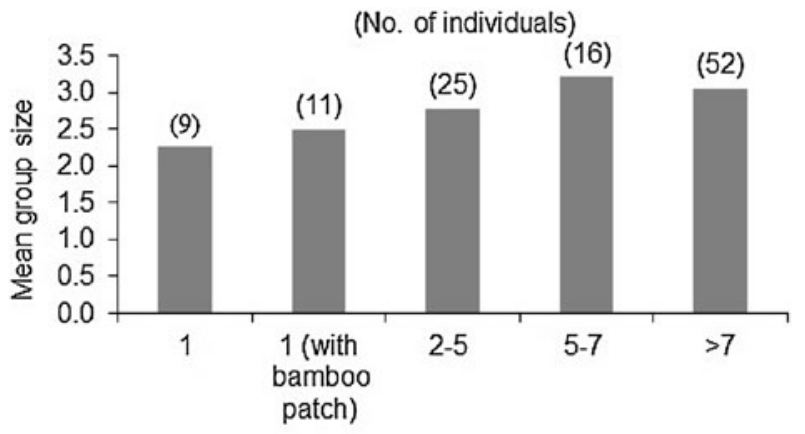

No. of trees per stand

FIG. 2 Mean group size of eastern hoolock gibbons in stands of different numbers of trees in the study area, in the Lower Dibang Valley district, Arunachal Pradesh, India (Fig. 1). The numbers above the columns are the total numbers of individuals counted.

predators of gibbons, particularly of immature animals. Dogs are opportunistic predators, capturing gibbons when they descend to the ground to move from one patch to another in search of food and secure sleeping places.

\section{Discussion}

Gibbons are known to occur in the tropical evergreen, tropical wet evergreen, tropical semi-evergreen, tropical moist deciduous and subtropical hill forests of South-east Asia. The geographical range of the eastern hoolock gibbon in India is contiguous with its range in Myanmar through the Chukan pass in Changlang district (Das et al., 2006). The Chindwin River and the mountains on the India-

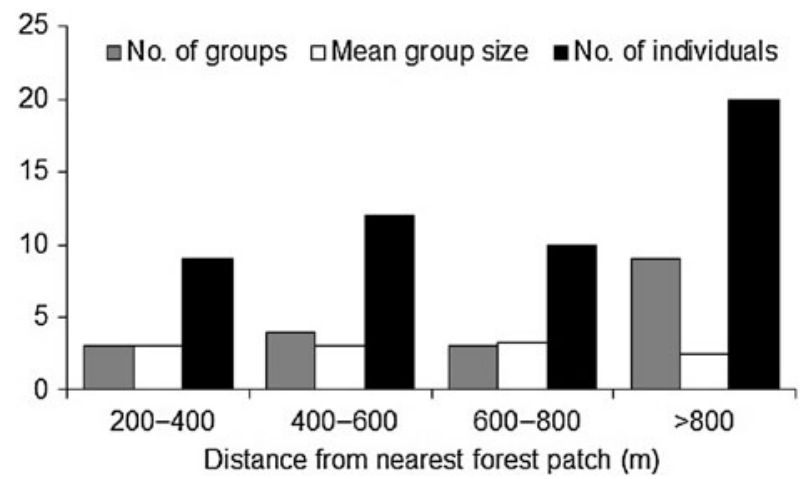

FIG. 3 Mean group size of eastern hoolock gibbons at various distances from the nearest forest patch in the study area, in the Lower Dibang Valley district, Arunachal Pradesh, India (Fig. 1).

Myanmar border are physical barriers to the distribution of the species. After the first distribution surveys of the eastern hoolock gibbon in India (Das et al., 2006; Chetry et al., 2008) a population survey was carried out in Mehao Wildlife Sanctuary, in the Lower Dibang Valley district of Arunachal Pradesh (Chetry et al., 2010). Gibbon occurrence in the area is dependent on the presence of the local Adi and Idu-Mishmi tribes; the Adi hunt gibbons, whereas the Idu-Mishmi do not. In this study we recorded gibbons in isolated trees and small patches of forest surrounded by agricultural land. The conversion of almost $50 \%$ of forest to agricultural land in the study area has led to canopy discontinuity, which prevents dispersal of the gibbons from one patch to another unless they descend to the ground. It also makes them more easily sighted by hunters and 


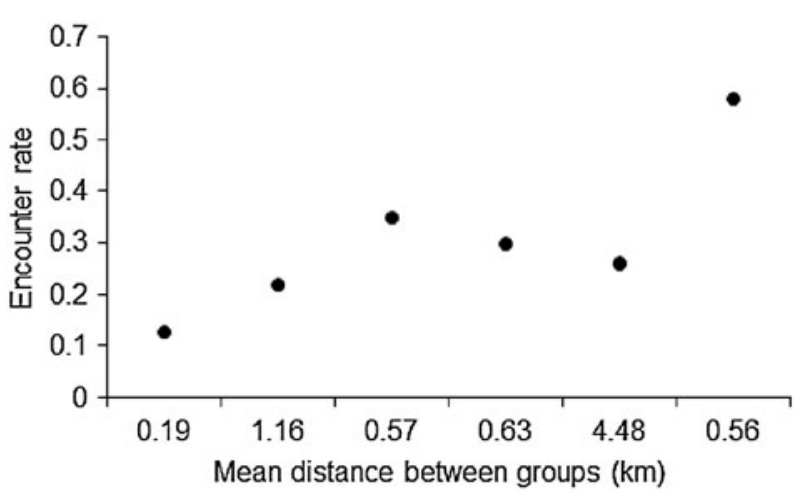

FIG. 4 The relationship between the encounter rate and the mean distance between groups of eastern hoolock gibbons in the study area, in the Lower Dibang Valley district, Arunachal Pradesh, India (Fig. 1).

potential predators such as domestic dogs and predatory birds such as the mountain hawk eagle Nisaetus nipalensis. Fragmentation also causes deterioration of the habitat and the elimination of suitable territories (Kakati et al., 2009) and reduces the availability of suitable mates and the genetic variability of the population (Jiang et al., 2006). The disappearance of gibbons from small forest fragments has been documented. Alfred \& Sati (1990) recorded the disappearance of western hoolock gibbons from 168 forest patches (0.14-2.7 km²) in jhum (slash-and-burn agriculture) matrices in the Garo Hills of Meghalaya. This occurred mainly because the jhum cycles (Kushwaha et al., 1981) had shortened to $<10$ years and gibbon dispersal corridors (secondary forests and old-growth bamboo) were no longer available.

Little information is available on the populations of the eastern hoolock gibbon in India. Other surveys have estimated 51 groups (168 individuals) in Namsai Forest Division, 10 groups (24 individuals) in Koronu Circle, 157 groups ( $>88$ individuals) in Mehao Wildlife Sanctuary, in Arunachal Pradesh, and 23 groups in Sadiya Forest Division, in Assam (Das et al., 2006; Chetry et al., 2008, 2010; Chetry \& Chetry, 2010). Our study has added to the knowledge of the Indian population of the species and highlighted the conservation importance of the fragmented population in the non-protected forest areas of Arunachal Pradesh.

The mean group size varies between habitats and depends on the level of anthropogenic disturbance. The highest mean group size for eastern hoolock gibbon (3.37) was reported in the Namsai Forest Division, Lohit district (Das et al., 2006), followed by 3.14 and 2.4 in Lower Dibang Valley district in Arunachal Pradesh (Chetry et al., 2008, 2010). The smaller mean group size (2.89) in our study area relative to other parts of the species' range (e.g. 3.9 in China; Brockelman et al., 2009; Fan et al., 2011) may be a result of forest fragmentation and human disturbance. We found the ratio of infants to adult females to be similar in all seven study sites (i.e. breeding rates were similar) but the absence of juveniles indicates that their survival may be affected by fragmentation and lack of food. Female gibbons in forest fragments probably suffer high lactation costs because of an inadequate diet (Kakati et al., 2009), both in quality and quantity. In such a situation dependent infants are more likely to die when they stop suckling. When resources are scarce females may not survive to breed again (Moir, 1994).

Chetry et al. (2008) reported forest loss and fragmentation in Lower Dibang Valley district as a result of extensive agricultural practices (e.g. tea, ginger, corn and mustard cultivation). We identified activities such as firewood collection, selective tree felling, and encroachment for permanent settlement as indirect threats that may affect the gibbon population. Almost 50\% of the total forest loss has occurred during the last 25 years, restricting the gibbons to small fragments of forest. Single-tree groups are most at risk as they are smaller than groups in forest patches. Although hunting is not widespread in Idu-Mishmi tribal areas, even a low level of hunting can significantly affect the gibbon population (Fan \& Jiang, 2007). Hunting pressure has apparently led to the local extinction of the gibbon in the Adi-dominated area. In a tribal state such as Arunachal Pradesh, where hunting is part of the local culture, it is difficult to implement wildlife laws and protect species listed under the Indian Wildlife (Protection) Act, 1972. In addition to hunting and poaching, attacks by domestic dogs are a threat (Panor, 2011). According to local people, domestic dogs sometimes attack gibbons, particularly immature animals that descend to the ground to move between forest patches.

Hoolock gibbons have been characterized as predominantly frugivorous (Chivers, 1974; Tilson, 1979; Alfred \& Sati, 1994), with fruits constituting up to $70 \%$ of their diet (Chivers, 1984; Islam \& Feeroz, 1992; Ahsan, 2001; Bartlett, 1999). However, our study indicated a more folivorous diet comprising $65 \%$ leaves and only $29 \%$ fruits and figs. Other studies have also recorded a significant reduction in the fruit content of the diet (Mukherjee, 1986; Kakati, 1997). Although it has been noted that folivory in hoolock gibbons increases during the wet (monsoon) season, when fruit tends to be less abundant (Gittins \& Tilson, 1984; Alfred \& Sati, 1994), our study was carried out in May, when fruits are normally more readily available than at other times. A study of the species' diet across seasons is needed to assess annual dietary variation.

Fan et al. (2011) recommended long-term population monitoring to determine whether hoolock gibbons can disperse between fragmented forest patches. For effective conservation management of gibbons and their habitat ongoing evaluation of their status is necessary, particularly in areas that hold a comparatively large proportion of the total population in India (Struhsaker et al., 1975; Wilson \& 
TABLE 3 Land use/land cover change matrix for the study area during 1985-2010. The numbers indicate the change in area $\left(\mathrm{km}^{2}\right)$; e.g. 171.62 $\mathrm{km}^{2}$ forested land was converted to cultivated land, and a total of $346.51 \mathrm{~km}^{2}$ of forested land was converted to other land uses.

\begin{tabular}{llllll}
\hline \multirow{2}{*}{$\begin{array}{l}\text { Sum of area }\left(\mathrm{km}^{2}\right) \\
1985\end{array}$} & \multicolumn{2}{l}{} & & & \\
\cline { 2 - 6 } & Cultivated land & Water body & Forested land & Built-up area & Total \\
\hline Cultivated land & 137.20 & 2.25 & 28.90 & 1.41 & 169.76 \\
Water body & 8.18 & 25.33 & 6.07 & 0.00 & 39.59 \\
Forested land & 171.62 & 24.16 & 144.98 & 3.75 & 3.27 \\
Built-up area & 0.03 & 0.00 & 0.08 & 10.42 & 3.38 \\
Total & 317.04 & 51.74 & 180.02 & & 559.23 \\
\hline
\end{tabular}

Wilson, 1975). We recommend habitat improvement through reforestation, and construction of canopy bridges to connect remnant forest patches. The translocation of gibbons from the Delo area to forested areas in the Mehao Wildlife Sanctuary as a part of a conservation action plan that has been initiated by the Wildlife Trust of India, in collaboration with the Forest Department, Arunachal Pradesh, must focus on saving isolated populations or groups that are at risk of extirpation. However, the foremost requirement for better conservation of the species is increased awareness and involvement of the local communities in addressing the threats of forest cutting and agricultural expansion.

\section{Acknowledgements}

We thank the PCCF (Wildlife), Itanagar, for permission to carry out this research. We also thank Dr C.L Sharma, Dr Prabal Sarkar, Mr Raju Barthakur, Dr Jyotishman Deka, and Mr Biranjay Basumatary for their support and guidance, the NRDMS Division (DST) for the financial support for this research, and the anonymous reviewers for their comments.

\section{References}

AhsAn, M.F. (2001) Socio-ecology of the hoolock gibbon (Hylobates hoolock) in two forests of Bangladesh. In The Apes: Challenges for the 21st Century, pp. 286-299. Chicago Zoological Society, Brookfield, USA.

Alfred, J.R.B. \& Sati, J.P. (1990) Survey and census of the hoolock gibbon in West Garo Hills, Northeast India. Primates, 31, 299-106.

Alfred, J.R.B. \& Sati, J.P. (1994) Diet and feeding in the hoolock gibbon of Garo Hills in North-eastern India. Annals of Forestry, 2, 109-122.

Altmann, J. (1974) Observational study of behavior: sampling methods. Behaviour, 49, 227-267.

B artlett, T. (1999) The gibbons. In The Nonhuman Primates (eds P. Dohlinow \& A. Fuentes), pp. 44-49. Mayfield Publishing Company, Mountain View, USA.

Brockelman, W. \& Geissmann, T. (2008) Hoolock leuconedys. In IUCN Red List of Threatened Species v. 2012.1. Http://www. iucnredlist.org [accessed 6 July 2012].

Brockelman, W.Y., Naing, H., Saw, C., Moe, A., Linn, Z., Moe, T. K. \& WIN, Z. (2009) Census of eastern hoolock gibbons (Hoolock leuconedys) in Mahamyaing Wildlife Sanctuary, Sagaing Division,
Myanmar. In The Gibbons: New Perspectives on Small Ape Socioecology and Population Biology (eds S. Lappan \& D. J. Whittaker), pp. 435-452. Springer, New York, USA.

Champion, H.G. \& Seth, S.K. (1968) Revised Survey of Forest Types of India. Government of India Press, New Delhi, India.

Chetry, D., Chetry, R., Das, A., Loma, C. \& Panor, J. (2008) New distribution records for Hoolock leuconedys in India. Primate Conservation, 23, 125-128.

Chetry, D., Chetry, R., Ghosh, K. \& Singh, A.K. (2010) Status and distribution of the eastern hoolock gibbon (Hoolock leuconedys) in Mehao Wildlife Sanctuary, Arunachal Pradesh, India. Primate Conservation, 25, 87-94.

Chetry, R. \& Chetry, D. (2010) First record of eastern hoolock gibbon in Assam, India. Primate Conservation, 25, 95-97.

Chivers, D.J. (1974) The siamang in Malayasia: a field study of a primate in tropical rain forests. Contributions to Primatology, 4, $1-335$.

Chivers, D.J. (1984) Feeding and ranging in gibbons: a summary. In The Lesser Apes: Evolutionary and Behavioural Biology (eds H. Preuschoft, D.J. Chivers, W.Y. Brockelman \& N. Creel), pp. 267-281. Edinburgh University Press, Edinburgh, UK.

Das, J., Biswas, J., Bhattacharjee, P.C. \& Mohnot, S.M. (2006) First distribution records of the eastern hoolock gibbon (Hoolock hoolock leuconedys) from India. Zoos' Print Journal, 21, 2316-2320.

Das, J., Feeroz, M.M., Islam, M.A., Biswas, J., Bujarborua, P., Chetry, D. et al. (2003) Distribution of hoolock gibbon (Bunopithecus hoolock hoolock) in India and Bangladesh. Zoos' Print Journal, 18, 969-976.

Fan, F.P., Wen, X., Sheng, H., Sen, A.H., Can, W.T. \& TaO, L.R. (2011) Distribution and conservation status of the Vulnerable eastern hoolock gibbon Hoolock leuconedys in China. Oryx, 45, 129-134.

FAN, P.F. \& JiAnG, X.L. (2007) Population viability analysis for black crested gibbon (Nomascus concolor jingdongensis) in Dazhaizi at Mt Wuliang, Yunnan, China. Acta Ecologica Sinica, 27, 620-626.

Geissmann, T. (2007) Status reassessment of the gibbons: results of the Asian Primate Red List workshop 2006. Gibbon Journal, 3, 5-15.

GitTins, S.P. \& Tilson, R.L. (1984) Notes on the ecology and behavior of the hoolock gibbon. In The Lesser Apes: Evolutionary and Behavioral Biology (eds H. Preuschoft, D.J. Chivers,

W.Y. Brockelman \& N. Creel), pp. 258-266. Edinburgh University Press, Edinburgh, UK.

Groves, C.P. (1971) Geographic and individual variation in Bornean gibbons, with remarks on the systematics of the subgenus Hylobates. Folia Primatologica, 14, 139-53.

Groves, C.P. (1972) Systematics and phylogeny of gibbons. In Gibbon and Siamang (ed. D.M. Rumbaugh), pp. 1-89. Karger, Basel, Switzerland.

Gupta, A.K., Sharma, N., Dasgupta, S., Chakraborty, D. \& HAZARIKA, R. (2005) Conservation of hoolock gibbon 
(Bunopithecus hoolock) in northeast India. ENVIS Bulletin: Wildife and Protected Areas, 8-252.

Harlan, R. (1934) Description of a species of Orang from the North-eastern Province of British East India, lately the Kingdom of Assam. Trans American Philosophical Society, 4, 52-59.

Islam, M.A. \& Feeroz, M.M. (1992) Ecology of hoolock gibbon of Bangladesh. Primates, 33, 451-464.

JiANG, X.L., Luo, Z.H., ZHAO, S.Y., Li, R.Z. \& LiU, C.M. (2006) Status and distribution pattern of black crested gibbon (Nomascus concolor jingdongensis) in Wuliang Mountains, Yunnan, China: implication for conservation. Primates, 47, 264-271.

KАКАтІ, K. (1997) Food selection and ranging in the hoolock gibbon (Hylobates hoolock) in Borajan Reserve Forest, Assam. MSc thesis. Wildlife Institute of India, Dehradun, India.

Kakati, K., Raghavan, R., Chellam, R., Qureshi, Q. \& Chivers, D.J. (2009) Status of western hoolock gibbon (Hoolock hoolock) populations in fragmented forests of eastern Assam. Primate Conservation, 24, 127-137.

KAUL, R.N. \& HARIDASAN, K. (1987) Forest types of Arunachal Pradesh-a preliminary study. Journal of Economic \& Taxonomic Botany, 9, 379-389.

Kumar, A., Marcot, B.G. \& Saxena, A. (2006) Tree species diversity and distribution patterns in tropical forests of Garo Hills. Current Science, 91, 1-12.

Kushwaha, S.P.S., Ramakrishnan, P.S. \& Tripathi, R.S. (1981) Population dynamics of Eupatorium odoratum in successional environments following slash and burn agriculture. Journal of Applied Ecology, 18, 529-536.

Lwin, N., Geissmann, T., Aung, S.S., Aung, T.N., Aung, Z.M., Hla, T.H. et al. (2011) The Myanmar hoolock gibbon conservation status review: first results. Gibbon Journal, 6, 13-17.

MoIr, R.J. (1994) The carnivorous herbivores. In The Digestive System in Mammals: Food, Form and Function (eds D.J. Chivers \& P. Langer), pp. 87-102. Cambridge University Press, Cambridge, UK.

Mootnick, A. \& Groves, C.P. (2005) A new generic name for the hoolock gibbon (Hylobatidae). International Journal of Primatology, 26, 972-976.
Mukherjee, R.P. (1986) The ecology of the hoolock gibbon, Hylobates hoolock, in Tripura, India. Journal of the Zoological Society of India, $34,70-81$.

PANOR, J. (2011) Outings with hoolock of Delo. Zoos' Print Journal, 12, 19-20.

QGIS (2012) A free and open-source geographic information system. Http://www.qgis.org [accessed September 2013].

Struhsaker, T.T. (1975) The Red Colobus Monkey. University of Chicago Press, Chicago, USA.

Sykes, J.M. \& Horrill, A.D. (1977) Vegetation Monitoring in Indian Tiger Reserves. A report to WWF. Merlwood Research Station, Grange-over-Sands, UK.

Tilson, R.I. (1979) Behavior of hoolock gibbon (Hylobates hoolock) during different seasons in Assam, India. Journal of Bombay Natural History Society, 76, 1-16.

Walker, S., Molur, S., Brockelman, W.Y., Das, J., Islam, A., Geissmann, T. \& Fan, P.F. (2009) Western hoolock gibbon Hoolock hoolock (Harlan, 1831). In Primates in Peril: The World's 25 Most Endangered Primates 2008-2010 (eds R.A. Mittermeier, J. Wallis, A.B. Rylands, J.U. Ganzhorn, J.F. Oates, E.A. Williamson et al.), pp. 62-64. IUCN/Species Survival Commission Primate Specialist Group, International Primatological Society, and Conservation International, Arlington, USA.

Wilson, C.C. \& WiLSON, W.L. (1975) The influence of selective logging on primates and some other animals in East Kalimantan. Folia Primatologica, 23, 245-274.

\section{Biographical sketches}

Kuladip SARma studies the behavioural ecology and conservation biology of the eastern hoolock gibbon in India. MURALI KRISHNA studies the habitat structure and resource quality for the eastern hoolock gibbon in India and has also carried out research on the flying squirrel of Arunachal Pradesh. Awadhesh Kumar is a primatologist and his research focus is on the ecology and conservation biology of primates in the Eastern Himalayan Biodiversity Hotspot. 